\title{
Pneumocystis carinii Pneumonia, Pulmonary Tuberculosis and Visceral Leishmaniasis in an Adult HIV Negative Patient
}

Antonio Carlos Toledo Jr. and Márcio Rodrigues de Castro
Eduardo Menezes Hospital, Hospitalar

Foundation of Minas Gerais, MG, Brazil

This is a case report of a 29 year old male with pneumocystis pneumonia and tuberculosis, and who was initially suspected of having HIV infection, based on risk factor analyses, but was subsequently shown to be HIV negative. The patient arrived at the hospital with fever, cough, weight loss, loss of appetite, pallor, and arthralgia. In addition, he was jaundiced and had cervical lymphadenopathy and mild heptosplenomegaly. He had interstitial infiltrates of the lung, sputum smears positive for Mycobacterium tuberculosis and Pneumocystis carinii, and stool tests were positive for Strongyloides stercoralis and Schistosoma mansoni. He was diagnosed as having AIDS, and was treated for tuberculosis, pneumocystosis, and strongyloidiasis with a good response. The patient did not receive anti-retroviral therapy, pending outcome of the HIV tests. A month later, he was re-examined and found to have worsening hepatosplenomegaly, pancytopenia, fever, and continued weight loss. At this time, it was determined that his HIV ELISA antibody tests were negative. A bone marrow aspirate was done and revealed amastigotes of leishmania, and a bone marrow culture was positive for Leishmania species. He was treated with pentavalent antimony, $20 \mathrm{mg}$ daily for 20 days, with complete remission of symptoms and weight gain. This case demonstrates that immunosuppression from leishmaniasis and tuberculosis may lead to pneumocystosis, and be misdiagnosed as HIV infection. The occurrence of opportunistic infections in severely ill patients without HIV must always be considered and alternate causes of immunosuppression sought.

Key Words: Pneumocystis carinii, visceral leishmaniasis, tuberculosis, HIV diagnosis, opportunistic infections.

We describe a case of $P$. carinii pneumonia as a complication of visceral leishmaniasis in an HIV negative patient. Visceral leishmaniasis (VL) is a chronic infectious disease characterized by an important immunological dysfunction that predisposes to other infections, mainly involving the pulmonary and gastrointestinal systems. In Brazil, bacterial pneumonia and tuberculosis are frequent opportunistic infections in this disease. $P$. carinii is a ubiquitous organism that

Received on 31 March 2001; revised 27 May 2001.

Address for correspondence: Dr. Antonio Carlos Toledo Jr. Rua Mário Coutinho, 541/304, Zip code: 30570-310 - Belo Horizonte-MG-Brazil. Phone (55 31) 3290-2968. Fax (55 31) 3290-2977.

The Brazilian Journal of Infectious Diseases 2001;5(3):154-157 (C) 2001 by The Brazilian Journal of Infectious Diseases and Contexto Publishing. All rights reserved.

$1413-8670$ commonly causes disease in immunodeficient patients such as in cancer, HIV/AIDS, leukemia, lymphoma, and transplant recipients [1]. Although there is no description of $P$. carinii pneumonia as an opportunistic infection of VL in the medical literature, it is plausible that immunodysfunction induced by Leishmania could be responsible for this patient's illness. If so, this would be the first description of an association of VLand $P$. carinii pneumonia.

\section{Case report}

A 29 year old male patient, was admitted to Hospital Eduardo de Menezes (Infectious Diseases Hospital of Minas Gerais State, Brazil) on October 16, 1995. He complained of fever, asthenia, weight loss (>10 kg), loss of appetite, generalized arthralgia and a productive cough. Past history indicated 2 blood transfusions and 
unsafe heterosexual sexual practice with multiple partners, including female prostitutes in Santos (the largest Brazilian port city, and a very high prevalence of HIV/AIDS). Physical exam showed jaundice, pallor, cervical lymphadenopathy, and mild hepatosplenomegaly. Laboratory tests showed anemia (hemoglobin $8.2 \mathrm{mg} / \mathrm{dl}$ ), leukopenia $(1,700$ cells/ $\left.\mathrm{mm}^{3}\right)$, and a normal platelet count $(143,000)$. Chest radiography revealed mild interstitial infiltrates. Sputum smear identified Mycobacterium tuberculosis (3 samples) and Pneumocystis carinii (histology - 1 sample). A blood sample for HIV serology was taken after the proper consent was obtained. Other laboratory findings were: blood smear negative for malaria, stool exams showed Strongyloides stercoralis and Schistosoma mansoni, blood cultures negative ( 2 samples), sputum cultures negative (2 samples), VDRL negative, FTA-Abs positive, and HbsAg negative.

The initial diagnoses were: schistosomiasis mansoni, strongyloidiases, disseminated tuberculosis, $P$. carinii pneumonia, and possible HIV infection. There was a good response to specific treatment including oxamniquine; thiabendazole; rifampin, isoniazid and pyrazinamide; and co-trimoxazole in high dose (15 $\mathrm{mg}$ of trimethoprim/kg/day), respectively. He was discharged in a very good condition on November 9 , 1995, and referred to the hospital outpatient clinic. The HIV serologic test results were not available at the time of discharge.

The patient did not go to the outpatient clinic and, on December 20, he was hospitalized again with the same symptoms (fever, moderate hepatosplenomegaly and significant weight loss). At that time, he also had a low platelet count associated with persistent anemia and leukopenia. Clinical deterioration was associated with reduction of co-trimoxazole dose from a therapeutic to a prophylactic one (2,400 $\mathrm{mg}$ to 800 $\mathrm{mg}$ of trimethoprim/day). He had continued regular use of the antituberculosis drugs. Serologic testing for HIV on two different samples was negative by ELISA for HIV antibodies. Stool and sputum exams were negative, showing good response to schistosomiasis, strongyloidiasis, and tuberculosis treatments.
Re-evaluation of the case was done. This was a male young adult patient with fever, moderate hepatosplenomegaly, pancytopenia, and cachexia (weight loss $>15 \mathrm{~kg}$ ) who was not infected with HIV. At this point, the differential diagnosis was changed to include: visceral leishmaniasis (VL), leukemia, lymphoma, and histoplasmosis. The epidemiological history identified possible cases of VL in his neighborhood. Bone marrow aspiration smear and culture identified Leishmania sp., confirming visceral leishmaniasis (kala-azar) as a main diagnosis. VL treatment was initiated on December 29, with meglumine antimonate (Glucatime ${ }^{\circledR}$ ) at a dose of 20 $\mathrm{mg}$ of antimoniate $/ \mathrm{kg} / \mathrm{day}$ for 20 days. There was complete remission of symptoms. On January 18, 1996, the patient was discharged and referred to the outpatient clinic. At that time he had a weight gain of $15 \mathrm{~kg}$, mild hepatosplenomegaly, and no other symptoms.

\section{Discussion}

The initial presentation was compatible with an advanced HIV infection phase complicated by disseminated tuberculosis and $P$. carinii pneumonia. Anemia, leukopenia, mild hepatosplenomegaly, and cachexia could be explained by HIV or by tuberculosis [2-9]. At that time, the patient did not present a low platelet count, a frequent observation in kala-azar [10]. Fever, cough, and a radiologic image of interstitial infiltrate could be related to $\mathrm{HIV}$, tuberculosis and $P$. carinii pneumonia [7-9]. A delay of HIV serology, and temporary VL response to high doses of cotrimoxazole contributed to the misdiagnosis of HIV infection and delayed the final diagnosis of kala-azar. Despite the low incidence of VL in urban areas of large Brazilian cities, it does exist and should be included in the differential diagnosis of any patient presenting fever, weight loss and low blood cell count.

Visceral leishmaniasis (VL) is an endemic disease in Brazil. During 1998, 1,809 new cases were reported to the Brazilian Ministry of Health [11]. VL is much more frequent in rural areas but, since the 1980s, urban autochtonous cases are being reported in large cities such as São Paulo, Rio de Janeiro, Belo Horizonte, 
Salvador, Natal, and Teresina [12-19]. Urban outbreaks are related to domestic dog infection [20, 21].

VL is characterized by an important immunological dysfunction. Ill patients do not develop a protective Th1 cell-mediated immune response, and delayed hypersensitivity responses are absent. An in vitro study showed that mononuclear cells do no proliferate and fail to produce interferon- $\gamma$ and interleukin- 2 in response to leishmanial antigens. Despite these, antileishmanial antibodies are produced at high titers by patients with progressive disease, and a hypergammaglobulinemia (polyclonal T-cell activation) is often observed [10, 22-24].

Leishmania has a great affinity to the reticuloendothelial system (RES). After inoculation, promastigotes forms convert to amastigotes in macrophages and disseminate through the RES, to mononuclear phagocytes. RES hyperplasia and hypertrophy are observed with disease progression. Reticuloendothelial modifications are easily observed in liver, spleen, and bone marrow. Besides RES involvement, inflammatory response against the parasite in interstitial tissues is the pathological base pf other organ manifestations (chest, bowel, skin, kidney) [10, 24, 25].

VL clinical manifestations vary according the degree of immunodeficiency. The incubation period ranges from 3 to 8 months, but can be as long as 34 months [14]. Commonly, patients present an insidious disease with gradual onset of symptoms. Fever, weakness, loss of appetite, splenomegaly, hepatomegaly, and weight loss are more frequently observed. Involvement of lung, pleura, oral mucosa, and small intestine are less frequent. Laboratory findings include anemia, leukopenia, low platelet count, and hypergammaglobulinemia [24-27].

Differential diagnosis includes malaria, schistosomiasis, typhoid fever, disseminated tuberculosis, histoplasmosis, prolonged Salmonella bacteremia, leukemia, lymphoma, and Gaucher's disease, among others [10, 24, 25, 30, 31].

A prevalent antimonial is the first choice for the initial treatment of VL. Recommended dose is $20 \mathrm{mg}$ of antimoniate/kg/day intravenous or intramuscular for 20 to 30 days. Patients should be hospitalized in the beginning of treatment because of possible serious adverse reactions. Interferon- $\gamma$ combined with pentavalent antimonial showed good response in patients who failed the antimonial alone, or relapsed after treatment [10, 24, 25]. There are some reports of temporary response to co-trimoxazole in high doses in refractory cases [32-35].

This case report emphasizes the need to search for all possible causes of immunosuppression in patients with opportunistic infections, not to assume that HIV infection is the causative immunosuppressive agent.

\section{References}

1. Walzer P. Pneumocystis pneumonia. In: Mandell G., Bennett J., Dolin R., eds. Principles and Practice of Infectious Diseases. Vol. 2. New York: Churchill Livingstone 1995:2478-5487.

2. Picon P., Rizzon C., Hoefel Filho J. Tuberculose de Disseminação Hemática. In: Picon P., Rizzon C., Ott W., eds. Tuberculose. Epidemiologia, Diagnóstico e Tratamento em Clínica e Saúde Pública. Rio de Janeiro: Medsi, 1993.

3. Doweiko J., Groopman J. Hematologic Complications of human immunodeficiency virus infection. In: De Vita Jr. V., Hellman S., Rosenberg S., eds. AIDS: Biology, Diagnosis, Treatment and Prevention. Philadelphia: Lippincott-Raven, 1997.

4. Goldenberg A. Hematologic abnormalities and mycobacterial Infections. In: Rom W., Garay S., eds. Tuberculosis. Boston: Little, Brown, 1996.

5. Hambleton J. Hematologic Complications of HIV infection. In: Sande M., Volberding P., eds. The Medical Management of AIDS. Philadelphia: WB Saunders, 1997.

6. Oyer R., Schlossberg D. Hematologic changes in tuberculosis. In: Schlossberg D., ed. Tuberculosis. New York: Springer-Verlag, 1994.

7. Afiune J. Tuberculose. Clínica e Diagnóstico. In: Veronesi R., Foccacia R., eds. Veronesi Tratado de Infectologia. São Paulo: Atheneu, 1996.

8. Hollander $H$. Initiating routine care for the HIVinfected adult. In: Sande M., Volberding P., eds. The Medical Management of AIDS. Philadelphia: WB Saunders, 1997.

9. Saag M. Clinical spectrum of human immunodeficiency virus disease. In: De Vita Jr. V., Hellman S., Rosenberg S., eds. AIDS: Biology, Diagnosis, Treatment and Prevention. Philadelphia: Lippincott-Raven, 1997. 
10. Badaró R., Duarte M. Leishmaniose visceral (Calazar). In: Veronesi R, Foccacia R, eds. Veronesi Tratado de Infectologia. Vol. 2. São Paulo: Atheneu, 1996:1234-59.

11. Ministério da Saúde. Casos notificados de doenças por UF e período especificado e acumulado no ano, Brasil, 1997 e 1998. Boletim Epidemiológico 1998;III:3.

12. Amato Neto V., Blanco Filho F. Leishmaniose visceral adquirida no estado de São Paulo (Brasil). Rev Saude Publica 1981; $15: 643-5$.

13. Iversson L., Pires R., Ribeiro M., et al. Investigação epidemiológica de um novo caso de leishmaniose visceral ocorrido na grande São Paulo, Brasil. Revista de Saúde Pública 1982;16:205-19.

14. Marzochi M., Coutinho S., de Souza W., et al. Canine visceral leishmaniasis in Rio de Janeiro, Brazil. Clinical, parasitological, therapeutical and epidemiological findings (1977-1983). Memórias do Instituto Oswaldo Cruz 1985;80:349-57.

15. Genaro O., da Costa C., Williams P., et al. Ocorrência de calazar em área urbana da grande Belo Horizonte, MG. Revista da Sociedade Brasileira de Medicina Tropical 1990;23:121.

16. Costa C., Pereira H., Araujo M. Visceral leishmaniasis epidemic in the State of Piaui, Brazil, 1980-1986. Rev Saud Publica 1990;24:361-72.

17. Jeronimo S., Oliveira R., Mackay S., et al. An urban outbreak of visceral leihmaniasis in Natal, Brazil. Trans Royal Soc Trop Med Hyg 1994;88:386-8.

18. Cunha S., Freire M., Eulalio C., et al. Visceral leishmaniasis in a new ecological niche near a major metropolitan area of Brazil. Trans Royal Soc Trop Med Hyg 1995;89:155-8.

19. Luz K., da Silva V., Gomes E., et al. Prevalence of antiLeishmania donovani antibody among Brazilian blood donnors and multiply transfused hemodialysis patients. Amer J Trop Med 1997;57:168-71.

20. Guardia J. Co-trimaxazole for kala-azar. Lancet 1981;1:501-2.

21. Arias J., Monteiro P., Zicker F. The re-emergence of visceral leishmaniasis in Brazil. Emerging Infectious Diseases 1996; 2: 145-6.

22. Campos-Neto A., Bunn-Moreno M. Polyclonal B cell activation in hamsters infected with parasites of the genus Leishmania. Infect Immun 1982;38:871-6.

23. Carvalho E.M., Bacellar O., Barral A., et al. Antigenspecific immunosuppression in visceral leishmaniasis is cell mediated. J Clin Invest 1989;83:860-4.

24. Pearson R., Sousa A. Leishmania species: visceral (kalaazar), cutaneous, and mucosal leishmaniasis. In: Mandell G., Bennett J., Dolin R., eds. Principles and Practice of Infectious Diseases. Vol. 2. New York: Churchill Livingstone, 1995:2428-42.

25. Mardsen P., Johnson Jr. W. Leishmania. In: Gorbach S, Bartlett J, Blacklow N, eds. Infectious Disease. Philadelphia: WB Saunders, 1998:2420-6.
26. Badaro R., Jones T.C., Carvalho E.M., et al. New perspectives on a subclinical form of visceral leishmaniasis. J Infect Dis 1986; 154:1003-11.

27. Badaro R., Jones T.C., Lorenco R., et al. A prospective study of visceral leishmaniasis in an endemic area of Brazil. J Infect Dis 1986; 154:639-49.

28. Berenguer J., Moreno S., Cercenado E., et al. Visceral leishmaniasis in patients infected with human immunodeficiency virus (HIV). Ann Intern Med 1989; 111:129-32.

29. Montalban C., Calleja J.L., Erice A., et al. Visceral leishmaniasis in patients infected with human immunodeficiency virus. Co-operative Group for the Study of Leishmaniasis in AIDS. J Infect 1990;21:26170 .

30. Medrano F.J., Hernandez-Quero J., Jimenez E., et al. Visceral leishmaniasis in HIV-1-infected individuals: a common opportunistic infection in Spain? AIDS 1992;6:1499-503.

31. Peters B.S., Fish D., Golden R., et al. Visceral leishmaniasis in HIV infection and AIDS: clinical features and response to therapy. Q J Med 1990;77:1101-11.

32. Thakur C., Sinha P. Inefficacy of ethambutol, ethambutol plus isoniazid, INH plus rifampicin, co-trimoxazole and metronidazole in the treatment of kala-azar. Journal of Tropical Medicine and Hygiene 1989;92:383-5.

33. Rodrigues-Cuartero A., Perez-Blanco F., Lopez-Fernandez A. Co-trimoxazole for visceral leishmaniasis. Infection 1990; 18:40.

34. Murphy K., Bong A. Co-trimoxazole for systemic leishmaniasis. Lancet 1981;1:323-4.

35. Chatterjee S., Chatterjee R. Visceral leishmaniasis treated with rifampicin and co-trimoxazole. Journal of the Indian Medical Association 1994;92:307. 